\title{
AN UNUSUAL CAUSE OF EPISTAXIS
}

\author{
Maj SK MAURYA ${ }^{*}$, Lt Col FB BHOT ${ }^{+}$
}

MJAFI 2001; $57: 342-343$

KEY WORDS :Epistaxis; Leech induced.

\section{Introduction}

$\mathbf{F}$ oreign body in the nose and nasopharynx is an important cause of unilateral epistaxis. A living foreign body or a parasite in the nose or nasopharynx is an uncommon cause. This cause should be considered when patients residing in hilly terrain present with unilateral epistaxis.

\section{Case Report}

A 12 year old boy, from a rural area was referred to the surgical OPD with complaints of pain and bleeding from the right nostril 2 months. There was no history of trauma, repeated nose picking or foreign body insertion. He also denied any history of sneezing or rhinorrhoea. The patient was a resident of a village in Himachal Pradesh and used to graze cattle in the field. Examination revealed, a young anxious child. General examination was essentially normal.

Local examination revealed a congested right nasal mucosa. Nasal septum was normal. Anterior part of right nasal cavity showed a fleshy greenish brown mass. It moved on exposure to light. He was diagnosed as a case of epistaxis due to a living foreign body (?leech). Removal was planned in the operation theatre. The patient was made comfortable in a sitting posture. The mass was held with a forceps and gentle traction given. Initially, difficulty was encountered. The mass could not be removed as one end was stuck. Common salt was sprinkled on the body of the leech and gentle traction continued. A live $6.5 \mathrm{~cm}$ leech was successfully removed. Bleeding from the nose was controlled by

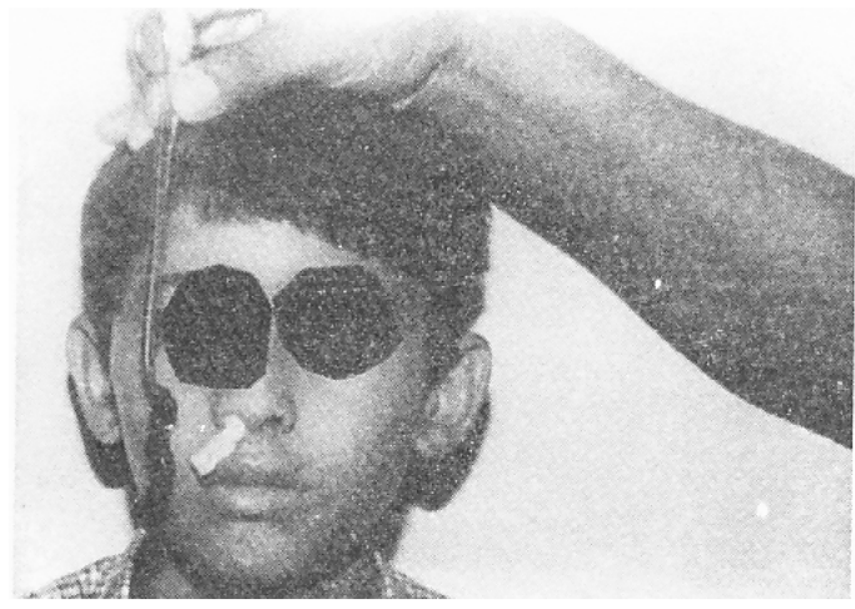

Fig. 1: Photograph showing a $6.5 \mathrm{~cm}$ leech after its removal an anterior nasal pack. The pack was removed after 24 hours. Re-examination of the nasal fossa after a period of 15 days revealed a normal healthy mucosa.

\section{Discussion}

Bleeding from the nose is a common clinical problem. $90 \%$ of the times epistaxis occurs from a plexus of vessels in the antero-inferior part of the nasal septum. In $10 \%$ cases, nasal bleeding is from the posterior part of the nose [1]. Epistaxis digitorum - nose picking, is the most frequent cause [2]. Leeches inhabit clean water in ponds, tanks, streams, and paddy fields [3]. Leech endoparasitisation occurs while bathing in ponds and streams or while working in the paddy fields. Nasal invasion of leech also occurs when the individual drinks water directly from the stream with his hands.

The commonest leech, Hirudinea medicinalis is an ectoparasite, which infests man and mammals. Dinobdella ferox, Limnatis linotica are other species of leeches, which cause nasal hirudiniasis [4,5]. Leeches attach themselves to the mucous membranes with the help of suckers and secrete an anticoagulant, hirudin. This results in painless bleeding which is often responsible for delay in seeking medical attention.

Various methods have been adopted for removal of the leech. In rural areas, application of common salt and tobacco to the leech is commonly used. Weak solution of chloroform, turpentine oil, $10 \%$ tartaric acid, 30\% cocaine and lighted end of cigarette butts are other methods employed for removal of leeches $[6,7]$.

Nasal infestation of leech usually results in mild epistaxis. Massive epistaxis and anaemia can occur. There have been reports of death due to leech infestation of nose and nasopharynx [8]. Leech endoparasitisation should be considered as a cause in unexplained epistaxis in areas where aquatic leeches are commonly found.

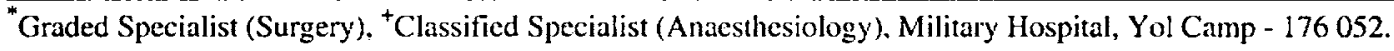




\section{References}

1. Snow JB Jr. Surgical disorders of ears, nose, Paranasal sinuses, pharynx and larynx. In : Sabiston DC, Jr editor. Textbook of surgery $15^{\text {th }}$ ed. Philadelphia. WB Saunders. 1997;1275-97.

2. Seward GR. The teeth and gums, jaws, nose, ear. In : Charles V Mann, RCG Russell, Normal S Williams, editor. Bailey and Love's Short practice of Surgery $22^{\text {nd }}$ ed. ELBS. 1995;450-69.

3. Kumar S, Dev A, Kochhar LK, Singh AM. Living leech in nose and nasopharynx. Indian Journal of Otolaryngology 1989;41:160-1

4. Campbell JR, Hart FL, Purnomo. Nasal leech infestation of man. Trop Geogr Med 1987;39(1):94-5.

5. Bergua A, Vizmanos F. Monzon FJ, Blasco RM. Unavoidable epistaxis in the nasal infestation of leeches. Acta Otorrinolarinngol Esp 1993;44(5):391-3.

6. Gupta SC. Nasal hirudiniasis in Kumaon hills, India. Trop Geogr Med 1980;32(4):303-5.

7. Kakar P, Sawney KL. Unilateral epistaxis : an unusual cause. Ann Otol Rhinol Laryngol 1965;74:158-61.

8. Cundall DB, Whitehead SM, Hechtel FD. Severe anemia and death due to the Pharyngeal leech Myxobdella africana. Trans R Soc Trop Med Hyg 1986;80(6):940-4. 